\title{
Valorization of Restaurant Waste Oil Over Cow-bone Doped Siliceous Termite Hills Catalysts Towards Biodiesel Production
}

\section{Babatunde Esther Olubunmi}

University of llorin Faculty of Engineering and Technology

\section{Saka H Bamidele}

University of Ilorin Faculty of Engineering and Technology

\section{Aderibigbe $\mathrm{F}$ Alade}

University of Ilorin Faculty of Engineering and Technology

\section{Yusuff Adeyinka}

Afe Babalola University

\section{Bisheswar Karmakar}

National Institute of Technology Durgapur

\section{Lalthazuala Rokhum}

National Institute of Technology Silchar

Gopinath Halder ( $\nabla$ gopinath_haldar@yahoo.co.in )

National Institute of Technology Durgapur

\section{Research Article}

Keywords: Biodiesel, Heterogeneous catalyst, Kinetic studies, Restaurant waste oil, Termite hill

Posted Date: June 14th, 2021

DOl: https://doi.org/10.21203/rs.3.rs-510139/v1

License: (c) (i) This work is licensed under a Creative Commons Attribution 4.0 International License. Read Full License 
1 Valorization of restaurant waste oil over cow-bone doped siliceous termite hills catalysts 2 towards biodiesel production

3 Babatunde E. Olubunmi ${ }^{1}$, Saka H. Bamidele ${ }^{1}$, Aderibigbe F. Alade ${ }^{1}$, Yusuff Adeyinka ${ }^{2}$.

4 Bisheswar Karmakar ${ }^{3}$, Lalthazuala Rokhum ${ }^{4}$, Gopinath Halder ${ }^{3 *}$

$5 \quad{ }^{1}$ Chemical Engineering Department, Faculty of Engineering, University of Ilorin, Kwara State, $6 \quad$ P.M.B 1515, Ilorin, Nigeria

$7{ }^{2}$ Department of Chemical and Petroleum Engineering, Afe Babalola University, Ado-Ekiti, $8 \quad$ Nigeria

$9{ }^{3}$ Department of Chemical Engineering, National Institute of Technology Durgapur, Durgapur10713209 , West Bengal, India

$11{ }^{4}$ Department of Chemical Engineering, National Institute of Technology Silchar, Silchar 788 12 010, Assam, India

18 Corresponding Author:

19 *Dr. Gopinath Halder

20 Professor, Department of Chemical Engineering,

21 National Institute of Technology Durgapur

22 M. G. Avenue, Durgapur- 713209

23 West Bengal, India.

24 Telephone: +91-94347-88189

25 E-mail address: gopinathhaldar@gmail.com 


\section{Abstract}

27 Treated termite hill is a potent heterogeneous catalyst in the synthesis of biodiesel from 28 restaurant waste oil (RWO). Two catalysts (raw cow-bone supported on silica; $\mathrm{R}_{-} \mathrm{SC}_{1.5}$ and 29 calcined cow bone supported on silica; $\mathrm{K}-\mathrm{SC}_{1.5}$ ) were developed and used in biodiesel 30 production. The maximum conversion of $\mathrm{RWO}$ was $95.12 \%$ using $\mathrm{K}-\mathrm{SC}_{1.5}$ at reaction time 2.5 $31 \mathrm{~h}$, methanol to oil ratio $9: 1$, temperature $65^{\circ} \mathrm{C}$ and catalyst loading of $2 \% \mathrm{w} / \mathrm{w}$. The prepared 32 catalysts were characterized using SEM, EDAX, FTIR, XRD and BET analysis. The kinetics of 33 the RWO with R-SC 1.5 and $\mathrm{K}-\mathrm{SC}_{1.5}$ was further studied. The $\mathrm{E}_{\mathrm{a}}$ and $\mathrm{A}$ were found to be $41.4 \mathrm{~kJ}$ $34 \mathrm{~mol}^{-1}, 53.41 \mathrm{~kJ} \mathrm{~mol}^{-1}$ and $2.24 \times 10^{4} \mathrm{~min}^{-1}, 2.29 \times 10^{6} \mathrm{~min}^{-1}$ respectively. The transesterification 35 reaction adhered to first order law, while physicochemical properties were within ASTM limits. 36 Reusability of $\mathrm{K}-\mathrm{SC}_{1.5}$ was also examined, which revealed effectiveness up to 5 reuses without 37 significant reduction in biodiesel yield.

42 Keywords: Biodiesel; Heterogeneous catalyst; Kinetic studies; Restaurant waste oil; Termite 43 hill. 


\section{Introduction}

54 In the world today, conventional fuels such as natural gas, coal, petroleum etc. are the major sources of energy, however their extensive use has an irreversible impact on the ecosystem through environmental pollution and global warming (Fadhila et al. 2017). Also, these fuels are non-renewable, and at the current rate of use, the tapped reserves are expected to decline critically within 50 years (Babatubde et al. 2020a). These problems prompted the search for substitute fuels which can be sustainably produced and consumed, with the added target of reduced toxic emissions upon combustion that may aid in reversing the climactic damage. These 'biofuels', so termed because of their origin from biomass based sources such as plants, animal or algae, have been accumulating research interest for the past few decades. Combined with other renewable sources such as wind, geothermal, hydroelectric, solar etc. the combined energy potential of these largely unused sources is far greater than can be from non-renewable energy sources, with ease of purification and use as well as energy density being the reasons for the latter's popularity. Biodiesel, being a form of biofuel, is gaining usage in engines and for power generation, yet widespread usage at this point is still largely impractical due to the scattered nature of potential resources. Biodiesel can be synthesized from renewable feedstocks, mainly edible or non-edible vegetable oils. Algae, animal fats, lard, and used oils from restaurants and households are also used as a cost-effective biodiesel feedstock (Dawodu et al. 2014). Polar alcohols (methanol, ethanol) are commonly used in a process known as 'transesterification' which involves conversion of glycerides or FFAs (free fatty acids) present in the feedstock into esters; however, recent studies by many researchers have shown that less polar alcohols such as 2-propanol are more effective in these conversions (Karmakar et al. 2021; Tan et al. 2010). Transesterification is also frequently coupled with esterification, usually as a pre-treatment step for oils that have high amounts of FFAs and are hence unsuitable for alkali-catalyzed conversion due to saponification and hydrolysis (Karmakar and Halder 2019). Here, polar alcohols could convert the FFAs into esters, usually aided by mineral acids that act as a catalyst, and non-polar alcohols are unable to participate in this conversion (Karmakar et al. 2020c). The benefits of biodiesel include biodegradability, high lubricity, low toxicity, high calorific value and high combustion efficacy due to increased oxygen (10 to 11\%) and virtually no sulphur. Nevertheless,

82 biodiesel commercialization is hindered by its high total cost of synthesis (Babatunde et al. 83 2020a). For catalyzed conversions, the prime factor that adds into production costs is catalyst 
preparation cost and recovery or washing, since homogenous catalysts provide high 'one-time; conversions but need to be washed away, typically over multiple rounds, while heterogeneous catalysts face issues of leaching and structural damage hindering their reusability apart from being costly to produce (Karmakar et al. 2018; Karmakar et al. 2020a). Additionally, feedstock procurement and processing (extraction, purification) amount for up to $30 \%$ of the total production costs, hence waste oils are a lucrative alternative (Dhawane et. al. 2018; Olutoye and Hammed, 2013). Therefore, there is a need to use low-cost feedstock such as restaurant waste oil (RWO) to reduce the total cost of biodiesel production and also solve the problem of fuel versus food competition (Jung et al. 2018). The Energy Information Administration estimated near 1 million gallon of RWO being generated per annum in USA alone. Also, in the EU countries, total RWO production was estimated to be 700,000 - 1,000,000 tons/year (Chhetri et al. 2008). Reports on RWO by several researchers have proven that it is a capable feedstock for biodiesel synthesis (Dhawane et al. 2018; Xiang-nan et al. 2019). Owolabi et al. and Rachael et al. established the efficiency of collected RWO as feedstock for biodiesel synthesis (Owolabi et al. 2011; Rachel et al. 2012). Kinetics of RWO transesterification needs to be elucidated for a better insight into its potential for scale-up (Ma et al. 2017). Most kinetic studies on RWO have been performed on processes that use homogeneous acids or bases as catalysts (Dhawane et al. 2018; Jain et al. 2011), however, process kinetics have not been studied by most researchers reporting their works on heterogeneous catalyzed conversions using novel synthetic catalysts.

Birla et al. reported the kinetic study of the transesterification of biodiesel from waste cooking oil using snail shell as catalyst (Birla et al. 2012). They found $E_{a}$ of $79 \mathrm{~kJ} / \mathrm{mol}$ and $\mathrm{A}$ of $2.98 \times$ $10^{14} \mathrm{~min}^{-1}$. Yusuf et al. reported transesterification kinetics of WCO conversion to biodiesel using anthill-eggshell-Ni-Co mixed oxide catalyst (Yusuf et al. 2017). The $E_{a}$ and A were found to be $23.99 \mathrm{~kJ} / \mathrm{mol}$ and $1.62 \times 10^{6} \mathrm{~min}^{-1}$ respectively. Comparing this result with Birla et al., it could be stated that the anthill-eggshell-Ni-co mixed oxide catalyst is faster due to lower $\mathrm{E}_{\mathrm{a}}$ and A, emphasizing the impact of catalyst nature on process kinetics (Birla et al. 2012; Moradi et al. 2015). According to Zhang et al., one way to reduce biodiesel synthesis cost is the full utilization of municipal or agricultural waste resources like cow bone (Ayoola et al. 2018), eggshell (Zabeti et al. 2009), snail shell (Birla et al. 2012; Laskar et al. 2018) as catalysts since they are rich in calcium and when properly activated (Zhang et al. 2010), are very stable with high surface area and porosity, resulting in enhanced catalytic performance. Among the calcium-rich waste 
materials, cow bone has been selected as the heterogeneous base catalyst as it is abundant in nature, readily available and inexpensive (Birla et al. 2012). Furthermore, the efficiency of this heterogeneous base catalyst could be improved if properly supported on suitable materials.

Several heterogeneous base catalysts supports have been utilized ranging from base catalyst supported on carbon material or silica material or alumina material or zeolite material or clay material to metal oxides (Changmai et al. 2020; Hossain et al. 2019; Minh et al. 2019). Although, other supports have also shown to be effective, base catalysts supported on silica have gained more attention for biodiesel production because of its inertness in addition to possessing high surface area and structural stability (Polshettiwar et al. 2009; Samart et al. 2010). Moreover, Farook et al. has documented similar report stating that silica provides ample surface area for any metal to disperse (Ciriminna et al. 2013; Farook et al. 2006). Hence, silica has been widely selected as a support for the base catalyst used in the biodiesel production. Precursors such as rice husk ash (Farook et al. 2006), tetramethoxysilane (TMOS), tetraethoxysilane (TEOS), tetrapropoxysilane (TPOS) (Paulino and Schuchardt 2002), microcrystalline silicon oxide, silica sol, water glass (Shaikh et al. 1993) and termite hill (Ganguli et al. 2013) are excellent sources of silica. Most of these sources are difficult to obtain and/or process, however, termite hills are indigenous to Nigeria and because of this natural abundance as well as their chemical inertness and thermal stability, they have been chosen as a catalyst support of the base catalyst used in this work (Karmakar et al. 2020a). Moreover, termite hill has also been found to contain some oxides and silicates of calcium, iron, aluminium and potassium which are also important catalyst for biodiesel production (Ganguli et al. 2013). A few works such as by Enagbonma et al. and Kumar et al. have reported the use of termite hill as useful sources of bacteria for biofuel production; and except for our previous work (Karmakar et al. 2020a), sufficient literature on the suitability of termite hills as an inert, porous catalyst support for biodiesel synthesis does not exist (Enagbonma et al. 2019; Kumar et al. 2015).

For this study, a heterogeneous catalyst was produced using silica derived from termite hill to support $\mathrm{CaO}$ rich material. Transesterification of restaurant waste oil occurred in the presence of the prepared catalyst for synthesis of biodiesel. Process parameters such as time, catalyst amount, reaction temperature and methanol to oil ratio were selected as the operating parameters. Kinetic study was carried out. The reaction rate constant $(\mathrm{k})$ and activation energy $\left(\mathrm{E}_{\mathrm{a}}\right)$ at different 
145 temperatures were elucidated. Fuel properties were also tested and equated with the American

146 Standard for Testing Materials (ASTM).

\section{Resources and procedure}

\subsection{Required materials}

149 The restaurant waste oil (RWO) used as feedstock was obtained from the school restaurant, 150 University of Ilorin, Kwara State, Nigeria. The RWO was preheated to eliminate moisture 151 contents and later filtered to remove impurities. Termite hill abundantly available in the local 152 area of Gidan Kwano, Minna, Nigeria, was selected as the precursor in preparing catalyst support 153 (called silica). The cow-bone was obtained from Saraki abattoir in Ilorin. Methanol (98.9\%) and $154 \mathrm{H}_{2} \mathrm{SO}_{4}(98.9 \%)$ were purchased from Sigma-Aldrich in Ilorin. Distilled water was obtained from 155 the Chemical Engineering Laboratory, University of Ilorin.

\subsection{Catalyst synthesis}

157 To prepare the support, the termite hill was pulverized into powder. The powder was dissolved in distilled water and mixed thoroughly and left standing for $36 \mathrm{~h}$. After decantation of the excess water, the termite hill was air-dried for 2 days, crushed into powder and dried again in an oven at $120{ }^{\circ} \mathrm{C}$ for $2 \mathrm{~h}$ to remove residual moisture. The powdered termite hill was sieved using $75 \mu \mathrm{m}$ mesh and kept in a desiccator. Thereafter, powdered $100 \mathrm{~g}$ of termite hill was mixed with $200 \mathrm{~mL}$ aqueous solution of $1 \mathrm{M} \mathrm{NaOH}$ under gentle agitation at $110{ }^{\circ} \mathrm{C}$ for $3 \mathrm{~h}$ (Putra et al. 2018). Resulting termite hill suspension was filtered and quenched by adding $300 \mathrm{~mL}$ ice-cold water, followed by filtration to obtain a silica type phase. Thereafter, it was repeatedly washed with hot distilled water to eliminate impurities as reported by Achyut et al., dried in the oven at $80{ }^{\circ} \mathrm{C}$ for $30 \mathrm{~min}$ and then labeled (S) (Achyut et al. 2010). In the same vein, collected cow-bone was washed, rinsed, dried, and ground into powder using a mechanical grinder, sieved and ovendried at $110{ }^{\circ} \mathrm{C}$ for obtaining a stable weight (called C).

169 To prepare the catalysts, the pretreated cow-bone (C) $1.5 \mathrm{wt} \%$ (relative to the weight of support) was added to $10 \mathrm{~g}$ silica. The mixture was dissolved in $50 \mathrm{~mL}$ water before being placed in an

171 orbital shaker at $200 \mathrm{rpm}$ and kept at $30{ }^{\circ} \mathrm{C}$ overnight. Filtration of the solution yields a solid 172 sample $\left(\mathrm{SC}_{1.5}\right)$, which was dried at room temperature for $24 \mathrm{~h}$ and called raw cow-bone 
173 supported on silica ( $\left.\mathrm{R}-\mathrm{SC}_{1.5}\right)$. The $\mathrm{R}-\mathrm{SC}_{1.5}$ was then calcined at $900{ }^{\circ} \mathrm{C}$ for $2 \mathrm{~h}$, and then called

174 calcined cow bone supported on silica $\left(\mathrm{K}-\mathrm{SC}_{1.5}\right)$ and then stored in a desiccator.

175

176

177

178

179

180

181

182

183

184

185

186

187

188

189

190

191

192

193

194

195

196

197

198

199

200

201

\subsection{Catalyst Characterization}

The prepared catalysts ( $\mathrm{R}-\mathrm{SC}_{1.5}$. and $\left.\mathrm{K}-\mathrm{SC}_{1.5}\right)$ were analyzed to estimate its physical properties such as surface area and pore volume. The analysis was performed using the multi-point BET (Brunauer Emmett Teller) method (Quantachrome instrument version 11.03, NOVA 2200E, Durham, USA). The catalysts were degassed at $196{ }^{\circ} \mathrm{C}$ under vacuum for $3 \mathrm{~h}$, which preceded the physical adsorption measurements. The time of analysis was 72.8 min using $\mathrm{N}_{2}$. A scanning electronic microscopy (SEM) [JEOL, JSM-6510LV, USA] was used to examine the surface morphological structure of the catalysts. The SEM displayed the image of the sample surface at a magnification of $100 \mu \mathrm{m}$ on a mode of $15 \mathrm{kV}$ average voltages and the elements present on the surface were quantified by using X-ray energy dispersive analysis (EDAX) using OXFORD Instrument INCAX-sight. The X-ray diffraction (XRD), EMPYREAN diffractometer system with $\mathrm{CuK} \alpha$ radiation of $(\lambda=1.54060 \AA)$ at $45 \mathrm{kV}$, step size of $2 \theta 0.0260$, scanning step time of 29.07 seconds and $40 \mathrm{~mA}$ between the range of $2 \theta=15.0024$ to $74.9684^{\circ}$ was used to determine the chemical phase and the crystalline structure of the functionalized catalyst. The presence of the functional groups was confirmed by using Fourier transform infrared spectrophotometer (Shimadzu FTIR-8400S, Canada) displaying a wave number spectrum between the range of 500 $\mathrm{cm}^{-1}-4000 \mathrm{~cm}^{-1}$.

\subsection{Conversion process}

Catalyst performance was examined during transesterification, conducted using a magnetic stirrer hotplate and a $250 \mathrm{~mL}$ round bottom flask attached with a condenser and a thermostat to maintain a constant temperature during the reaction. Based on $50 \mathrm{~g}$ of RWO, with constant agitation rate of $250 \mathrm{rpm}$, the reaction took place under the operating conditions of 9:1 methanol to oil ratio, a reaction time of $2.5 \mathrm{~h}$, catalyst loading of $2 \mathrm{wt} \%$ (for $\mathrm{R}-\mathrm{SC}_{1.5}$ and $\mathrm{K}-\mathrm{SC} \mathrm{C}_{1.5}$ ) and reaction temperatures of $50,55,60$, and $65^{\circ} \mathrm{C}$. After the reactions, each mixture was poured into separating funnels through filter paper to retain the catalyst for reuse. The filtrate mixture was allowed to separate overnight to obtain a clear layer of biodiesel. The produced biodiesel was collected, purified (through repeated wet-washing and drying) and volumetric fuel yield was 
202 calculated using Eq.1. To investigate the quality of the biodiesel synthesized, physico-chemical 203 tests were performed as per ASTM standards.

204 Biodiesel Yield $(\%)=\frac{\text { Weight of Biodiesel from RWO }}{\text { Weight of RWO used }} \times 100 \%$

\section{2.5. Kinetics of transesterification of RWO}

206 For kinetic studies, considered assumptions were:

207 1. Methanol concentration is in excess of required stoichiometric ratio and can be considered constant. Thus, the reversible reaction could be ignored as equilibrium is shifted towards product formation (Le Chatelier's principle).

2. The catalyst efficiently catalyzed every step-wise conversion of the transesterification, and the three consecutive reactions cycles occurred at the same rate as the overall rate of triglyceride conversion (Yusuff et al. 2017),

213 Moreover, Karmakar et al. have also reported that excess methanol is required to avoid the 214 conversion of glyceride while maintaining a forward reaction (Karmakar et al. 2020a). 215 Therefore, the rate law governing the forward reaction of transesterification reaction has been 216 expressed in Eq.2.

$217-R_{a}=\frac{-d[T G S]}{d t}=k^{\prime} .[T G] .[M t O H]^{3}$.

218 Where $-\mathrm{R}_{\mathrm{a}}=$ rate of reaction; $\mathrm{TG}_{\mathrm{s}}=$ triglyceride concentration, $\mathrm{k}$ ' = equilibrium rate constant, $219 \mathrm{MtOH}=$ methanol concentration. Since, the concentration of methanol did not alter the reaction 220 order, it is appropriate to theorize that the reaction adheres to a pseudo-first order reaction. 221 Hence, the Eq.3 has been adapted for the reaction order.

$222-R_{a}=\frac{-d[T G]}{d t}=k .[T G]$.

223 Where $\mathrm{k}$ is modified rate constant, and therefore $\mathrm{k}=\mathrm{k}^{\prime}[\mathrm{MtOH}]^{3}$. It has been assumed that at time $224 \mathrm{t}=0$, the initial concentration of triglycerides was $\mathrm{TG}_{0} \mathrm{~mol} / \mathrm{dm}^{3}$, and at time $\mathrm{t}$ it falls down to $225 \mathrm{TG}_{1}$. On integrating Eq.3 we have Eq.4, noting that $[T G]=\left[T G_{o}\right](1-X)$

$226-\ln (1-X)=k t$.

227 The graph of $-\ln (1-X)$ against $t$ at different reaction temperatures $\left(50{ }^{\circ} \mathrm{C}, 55^{\circ} \mathrm{C}, 60{ }^{\circ} \mathrm{C}\right.$, and 65 $228{ }^{\circ} \mathrm{C}$ ) was plotted to obtain the rate constants at each temperature. Furthermore, to determine the 
229

230

231

232

233

234

235

236

237

238

239

240

241

242

243

244

245

246

247

248

249

250

251

252

253

254

255

256

257

activation energy $\left(E_{\mathrm{a}}, \mathrm{kJ} / \mathrm{mol}\right)$ and the frequency factor $\left(\mathrm{k}_{\mathrm{a}}, \mathrm{min}^{-1}\right)$ of the reaction, the values of the rate constants obtained at different temperatures were plotted against the inverse of temperature.

\section{Results and discussion}

\subsection{Catalyst characterization}

\subsubsection{BET analysis}

The BET analysis of both $\mathrm{K}-\mathrm{SC}_{1.5}$ and $\mathrm{R}-\mathrm{SC}_{1.5}$ were performed and presented in Table 1 . The calcined cow bone supported on silica $\left(\mathrm{K}-\mathrm{SC}_{1.5}\right.$ ) shows a wider surface area of $440.88 \mathrm{~m}^{2} \mathrm{~g}^{-1}$ as compared to the raw cow bone supported on silica $\left(\mathrm{R}-\mathrm{SC}_{1.5}\right)$ with surface area of $260.70 \mathrm{~m}^{2} \mathrm{~g}^{-1}$. This indicates that during the calcination process, the components of the catalyst which tend to hold the particles together have been burnt off thereby increasing the areas to be occupied by the active sites. Furthermore, Birla et al. reported that a higher pore size of a catalyst is necessary as it allows proper diffusion of reactants into the active site of the catalyst (Birla et al. 2012). In this work, the pore size of $\mathrm{K}-\mathrm{SC}_{1.5}(22.90 \mathrm{~nm})$ was larger than $\mathrm{R}-\mathrm{SC}_{1.5}(21.24 \mathrm{~nm})$, hence, this allowed sufficient interactions between the catalyst, reactants and product molecules. The concentration of basic site of the catalyst was also investigated and the value of the $\mathrm{R}-\mathrm{SC}_{1.5}$ (9.40 mmol/g cat) was found to be lesser than $\mathrm{K}-\mathrm{SC}_{1.5}(10.90 \mathrm{mmol} / \mathrm{g}$ cat $)$, this result could be attributed to the oxides of calcium and other basic compounds as reported by Yusuff et al. Furthermore, it also indicates that Lewis base site contributed to high catalyst activity (Yusuff et al. 2017).

\subsubsection{Morphological analysis}

SEM studies in Fig. 1 shows the structural nature of the raw and calcined catalyst developed respectively. Fig. 1a revealed that the catalyst particles $(\mathrm{X})$ of $\mathrm{R}-\mathrm{SC}_{1.5}$ are agglomerated and heterogeneous. It possesses coarse and irregularly sized particles with smooth edges. This result is congruent to reports from Mitaphonna et al. when they stated that catalyst particles formed with uncalcined cow bone could be coarse and possess aggregate structure with smaller surface area (Mitaphonna et al. 2019). However, Fig. 1b obviously reveals a deviation in particle size (Y) after calcination (Kusuma and Chandrappa 2019). The particles tend to be dispersed and reduced in size with higher surface area. This indicates that the organic compounds in the K- 
$\mathrm{SC}_{1.5}$ have undergone decomposition, while the inorganic compounds have been converted to their oxides (Ganguli et al. 2013; Mitaphonna et al. 2019). The irregular sized particles tend to have rough edges $(\mathrm{Y})$ which is expected to enhance adequate interaction between the reactants. This result is also congruent to BET results from other studies (Babatunde et al. 2020a).

\subsubsection{EDAX analysis}

As shown in Fig. 2, the EDAX analysis reveals the elemental compositions of the $\mathrm{R}^{-\mathrm{SC}_{1.5}}$ and $\mathrm{K}$ $\mathrm{SC}_{1.5}$ respectively. The presence of silicon $(\mathrm{Si})$ aluminium $(\mathrm{Al})$, iron $(\mathrm{Fe})$, zinc $(\mathrm{Zn})$ and titanium (Ti) in the two catalysts was due to the natural composition of termite hill (as explained by Ganguli et al.), while the calcium (Ca) was impregnated from cow bone (Ganguli et al. 2013; Nisar et al. 2017). The $\mathrm{R}-\mathrm{SC}_{1.5}$ contains $63.1 \% \mathrm{Si}, 17.9 \% \mathrm{Ca}$ and $5.1 \% \mathrm{~K}$ while $\mathrm{K}-\mathrm{SC}_{1.5}$ has a higher percentage composition of $65.85 \%, \mathrm{Si}, 21.99 \%, \mathrm{Ca}$ and $6.9 \% \mathrm{~K}$. The results from the EDAX indicate that the calcination process had a notable effect on the catalyst composition (Farooq et al. 2015; Figueiredo et al. 2010). However, the reverse is seen for aluminium (Al), iron $(\mathrm{Fe})$, zinc $(\mathrm{Zn})$, magnesium $(\mathrm{Mg})$ and titanium $(\mathrm{Ti})$ where their compositions were shown to be higher in $\mathrm{R}-\mathrm{SC}_{1.5}$ than $\mathrm{K}-\mathrm{SC}_{1.5}$. These elements may have also enhanced the catalytic performance of $\mathrm{R}-\mathrm{SC}_{1.5}$ during the transesterification reaction even without calcination. Lastly, a slight change was also noticed in the percentage composition of sodium (from $2.07 \%$ to 1.73 $\%$ ) and aluminium (from $0.13 \%-0.07 \%$ ) between the two catalysts. Also, Table 2 shows the chemical composition of the calcined cow bone as determined by XRF analysis. It reveals the presence of $\mathrm{CaO}(62.81 \%)$ and $\mathrm{P}_{2} \mathrm{O}_{5}$ (35.4\%) and other compounds in lower quantity. The result implies that cow bone is a suitable source of catalyst for biodiesel production. The reported work by Nisar et al. shows good agreement with the findings reported in this study (Nisar et al. 2017). Moreover, the cow bone contains $\mathrm{Fe}_{2} \mathrm{O}_{3}(0.45 \%), \mathrm{CuO}(0.004 \%), \mathrm{ZnO}(0.015 \%), \mathrm{SrO}(0.161$ $\%), \mathrm{CeO}_{2}(0.071 \%), \mathrm{K}_{2} \mathrm{O}(0.25 \%)$ and $\mathrm{Li}_{2} \mathrm{O}(0.839 \%)$ at very low percentages. Even at lower percentage, they could also have contributed to the catalyst reactivity. This further confirmed the results obtained from the EDAX analysis.

\subsubsection{Spectral analysis}

The X-ray diffraction analysis of the $\mathrm{K}_{-} \mathrm{SC}_{1.5}$ was further investigated to determine the size and crystallinity of the synthesized material. As shown in Fig. 3, $2 \theta$ values from $15^{\circ}-75^{\circ}$ reveal the nature and crystallinity of the materials. The peaks at $32.49^{\circ}$ and $53.62^{\circ}$ indicates the presence of 
$\mathrm{SiO}_{2}$ (quartz) in the form of a rhombohedra crystal. The peaks at $34.12^{\circ}, 47.11^{\circ}, 63.97^{\circ}, 68.11^{\circ}$, and $69.24^{\circ}$ also indicate the presence of $\mathrm{CaO}$ in the form of the cubic crystal system (Farooq et al. 2015). Hence, the XRD analysis revealed the presence of two prominent crystalline phases derived from silicon oxide $\left(\mathrm{SiO}_{2}\right)$ and calcium oxide $(\mathrm{CaO})$ (Lesbani et al. 2013). The traces of these compounds were also confirmed by elemental analysis. Presence of other compounds may be confirmed from other non-major peaks in the spectrum.

As depicted in Fig. 4, the FTIR spectrum of $\mathrm{K}_{-} \mathrm{SC}_{1.5}$ was also investigated. The wavenumber between $3400 \mathrm{~cm}^{-1}$ and $3650 \mathrm{~cm}^{-1}$ represents symmetric and asymmetric -OH stretching of $\mathrm{H}-$ bonded water which could be as a result of moisture adsorption or the presence of $\mathrm{Ca}(\mathrm{OH})_{2}$ in trace amounts (Varadwaj et al. 2013). The wavenumber $1600 \mathrm{~cm}^{-1}$ also revealed an $\mathrm{H}-\mathrm{O}-\mathrm{H}$ bending vibration of coordinated water molecules present in the interlayer structure. The wavenumbers $1428.39 \mathrm{~cm}^{-1}$ and $931.34 \mathrm{~cm}^{-1}$ can be correlated to stretching vibrations of $\mathrm{CO}_{3}^{-2}$ groups, in $\mathrm{CaCO}_{3}$ (Lesbani et al. 2013). According to Varadwaj et al., the absorption band at wavenumber $578.14 \mathrm{~cm}^{-1}$ also suggested the presence of $\mathrm{Ca}-\mathrm{O}$ as reported by (Varadwaj et al. 2013). Furthermore, the absorption spectrum at wavenumber $1096.11 \mathrm{~cm}^{-1}$ suggested the presence of silicate ion (Si-O stretch) as a functional group in the material (Yusuff et al. 2017). The presence of all these stretches and vibration bonds may have been responsible for the high reactivity of the calcined catalyst $\left(\mathrm{K}_{-} \mathrm{SC}_{1.5}\right)$.

Furthermore, FTIR of the biodiesel produced using $\mathrm{K}-\mathrm{SC}_{1.5}$ at $65^{\circ} \mathrm{C}$ under the stated conditions was examined. The spectrum in Fig. 5 shows the absorption band at wavenumber $3417.11 \mathrm{~cm}^{-1}$, suggesting that the $\mathrm{O}-\mathrm{H}$ stretching vibration may represent alcohols. The band of $1735.24 \mathrm{~cm}^{-1}$ suggests the vibration of double bonds stretching of ester carbonyl group of triglycerides $(\mathrm{C}=\mathrm{O}$ stretch) which may be due to the presence of methyl esters. Other bands seen were at wave numbers $1450.5 \mathrm{~cm}^{-1}, 1393.97 \mathrm{~cm}^{-1}$, and $749.23 \mathrm{~cm}^{-1}$ which may also depict the presence of C-O ester groups (Yusuff et al. 2018).

\subsection{Transesterification}

Reactions were conducted in the presence of $\mathrm{R}-\mathrm{SC}_{1.5}$ and $\mathrm{K}-\mathrm{SC}_{1.5}$ under the operating conditions of 9:1 (methanol to RWO ratio), reaction time of $2.5 \mathrm{~h}$, catalyst loading of $2 \mathrm{wt} \%$ relative to RWO and reaction temperatures of 50, 55, 60, and $65^{\circ} \mathrm{C}$ (Adepoju et al. 2020; Nisar et al. 2017). The temperature was varied between $50-65^{\circ} \mathrm{C}$ so as to investigate the kinetics of the reaction. In 
Fig. 6, the RWO conversion tends to increase as the reaction temperature increases. The maximum yields attained by $\mathrm{R}-\mathrm{SC}_{1.5}$ and $\mathrm{K}-\mathrm{SC}_{1.5}$ were $68.1 \%$ and $95.12 \%$ respectively. Hence, it is worthy of note to state that the higher conversion attained by $\mathrm{K}-\mathrm{SC}_{1.5}$ was due to the influence of calcination on the catalyst (Farooq et al. 2015).

\subsection{Fuel properties}

Physicochemical properties of the FAMEs obtained using $\mathrm{K}-\mathrm{SC}_{1.5}$ as catalyst was examined and compared with values set by the American Standard for Testing Materials (ASTM). The results are congruent with reports from Chinyere et al. as shown in Table 3, where the values were found to be within required range (Chinyere et al. 2017). High flash point and fire point specify transportation and fuel storage efficiency. Substantial improvement in calorific value was observed which implies that the fuel is energy efficient. Since increased fuel viscosity results inefficient atomization due to low lubricity, the low kinematic viscosity observed in the fuel is responsible for improved performance. The delay in a fuel's ignition can be measured by cetane number of the obtained product. The API gravity value obtained (39.61) also confirmed that the RWO-biodiesel is less dense relative to the density of water (Karmakar et al. 2020a).

\subsection{RWO transesterification kinetics}

The influence of temperature and time (using $\mathrm{R}-\mathrm{SC}_{1.5}$ ) on $\mathrm{RWO}$ conversion is revealed in Fig. 7a. Although the conversion of $\mathrm{RWO}$ remains low compared to $\mathrm{K}-\mathrm{SC}_{1.5}$, the $\mathrm{R}-\mathrm{SC}_{1.5}$ could show potential towards higher conversion of RWO in further studies. The influences of temperature and time (using $\mathrm{K}_{-} \mathrm{SC}_{1.5}$ ) on $\mathrm{RWO}$ conversion is revealed in Fig. 7b. The effect of increasing the reaction temperature between $50{ }^{\circ} \mathrm{C}$ and $55^{\circ} \mathrm{C}$ was obvious even as time increases from $30 \mathrm{~min}$ to $60 \mathrm{~min}$. Also, the conversions curve tends to intersect each other between the reaction temperatures $55^{\circ} \mathrm{C}-60{ }^{\circ} \mathrm{C}$. However, as time and temperature increase, the curves tend to split. This commensurate with reports from literature, as increase in temperature allows the mass transfer and proper dispersion of catalyst molecules.

\subsubsection{Determining $E_{a}$ and $A$}

In order to deduce the kinetic parameters, $-\ln (1-\mathrm{x})$ was plotted against $t$ as shown in Fig. 8 and the correlation coefficients were $>0.9$ for both catalysts. As shown in Fig. 9, the $\mathrm{E}_{\mathrm{a}}$ and A were $41.4 \mathrm{~kJ} / \mathrm{mol}$ and $2.24 \times 10^{4} \mathrm{~min}^{-1}$ for $\mathrm{R}-\mathrm{SC}_{1.5}$ and $53.41 \mathrm{~kJ} / \mathrm{mol}$ and $2.29 \times 10^{6} \mathrm{~min}^{-1}$ for $\mathrm{K}-\mathrm{SC}_{1.5}$ 
respectively. These were determined by plotting $\ln (\mathrm{k})$ of rate constants for each temperature against the inverse of reaction temperatures $(1 / \mathrm{T})$. In this plot, the R-squared values for $\mathrm{R}-\mathrm{SC}_{1.5}$ and $\mathrm{K}-\mathrm{SC}_{1}$ were found to be 0.9501 and 0.9959 respectively. The result was in agreement with reported works as the range of $\mathrm{E}_{\mathrm{a}}$ observed in literature were mostly amid $33-84 \mathrm{~kJ} / \mathrm{mol}$ (Deshmane and Adewuyi 2013; Feyzi and Shahbazi 2017). Ea values vary depending on process, feedstock and catalyst type (Endalew et al. 2011). Krishnamurthy et al. reported an $E_{a}$ of 67.21 $\mathrm{kJ} / \mathrm{mol}$ and A of $5.182 \times 10^{8} \mathrm{~min}^{-1}$ from the transesterification of scum oil (Krishnamurthy et al. 2020). Furthermore, Birla et al. documented activation energy of $79 \mathrm{KJ} / \mathrm{mol}$ and $2.98 \times 10^{10} \mathrm{~min}^{-}$ ${ }^{1}$ in converting waste cooking oil through a heterogeneous catalyst (Birla et al. 2012).

\subsubsection{Reusability of $\mathrm{K}-\mathrm{SC}_{1.5}$}

The reusability tests aimed at establishing the extent of leaching were carried out when the first cycle of transesterification reaction was completed. The test was conducted for 5 consecutive cycles under reaction conditions discussed earlier in this study. After completion of the reaction, filtration ensured recovery of the catalyst, and a subsequent wash using methanol. The conversion remains stable for the first three cycles and reaches $90.45 \%$ at the end of the 5th cycle as shown in Fig. 10. The decrease in the yield of methyl ester is from the blockage of active catalytic sites in the support structure, along with loss of active metals from the catalyst due to leaching. This was in agreement with literature reports from Olutoye and Hameed, Adepoju et al. and by Karmakar et al. in their works with acid and base doped carbonaceous supports (Adepoju et al. 2020; Karmakar et al. 2020a; Karmakar et al. 2020b; Karmakar et al. 2020c; Karmakar et al. 2021; Olutoye and Hameed 2013).

\section{Conclusion}

In this study, we investigated biodiesel synthesis from restaurant waste oil (RWO) with $\mathrm{R}-\mathrm{SC}_{1.5}$ and $\mathrm{K}_{-} \mathrm{SC}_{1.5}$ as heterogeneous catalysts. The $\mathrm{K}-\mathrm{SC}_{1.5}$ was found to give maximum biodiesel conversion of $95.12 \%$ and fuel properties were found to be within ASTM limits. Also, based on maximum percentage conversion and information deduced from various characterizations such as SEM, FTIR, XRD, and EDAX, the kinetic studies of the restaurant waste oil was studied using $\mathrm{K}-\mathrm{SC}_{1.5}$. The $\mathrm{E}_{\mathrm{a}}$ and $\mathrm{A}$ were found to be $53.41 \mathrm{~kJ} / \mathrm{mol}$ and $2.29 \times 10^{6} \mathrm{~min}^{-1}$ respectively, which is congruent with most results reported in available literature. Hence, it could be stated that treated termite hill is a recommendable catalyst for the transesterification of RWO since it 
377 reduces the total cost of biodiesel production and can also help promote the commercialization of 378 biodiesel.

379 Ethics approval and consent to participate

$380 \quad$ Not applicable

381 Consent for publication

382 Not applicable

383 Availability of data and materials

384 All data generated or analyzed during this study are included in this article.

385 Competing interests

386 The authors declare that they have no competing interests.

$387 \quad$ Funding

388 No financial aid from any commercial or public agency was received towards completion of this 389 research.

390 Authors' contributions

391 BEO conceptualized the study and listed necessary resources. BK and BEO handled software 392 based experimental designing and formal analysis as well as data curation. They also wrote the 393 original draft. SHB, AFA and YA were the experimental investigators who also validated 394 obtained data, while GH was the supervisor and was in charge of this project. BK, LR and GH 395 took the responsibility of reviewing and editing the manuscript. GH handled submission related 396 procedures. The final version of the manuscript was read and approved by all authors.

397 Acknowledgements

398 The authors express their sincere gratitude to the technologists at the Department of Chemical 399 Engineering, University of Ilorin and Federal University of Technology Minna, Nigeria for their 400 immense support during execution of the work.

$401 \quad$ References 
Achyut KP, Mishra BG, Mishra DK, Singh RK (2010) Effect of sulphuric acid treatment on the physiochemical characteristics of kaolin clay. Coll Surf A: Phys Eng Asp 363(1-3):98-104. https://doi.org/10.1016/j.colsurfa.2010.04.022

Adepoju TF, Ibeh MA, Babatunde EO, Abegunde GS, Adepoju PO, Asuquo AJ, Osueke CO (2020) Datasets on process transesterification of binary blend of oil for fatty acid ethyl ester (FAEE) synthesized via the ethanolysis of heterogeneous doped catalyst. Data Brief 31:105905. https://doi.org/10.1016/j.dib.2020.105905

Ayoola AA, Igho EB, Babalola R, Ojewumi EM, Ajibola O, Oluwabunmi GA, Fayomi SO (2018) Production of biodiesel from soyabean oil using calcium oxide and cowbone as catalysts. Mater Focus 7(4):542-548. https://doi.org/10.1166/mat.2018.1530

Babatunde EO, Karmakar B, Aderemi OM, Akpan UG, Auta M, Halder G (2020a) Parametric optimization by Taguchi L9 approach towards biodiesel production from restaurant waste oil using Fe-supported anthill catalyst. J Env Chem Eng 6:104288. https://doi.org/10.1016/j.jece.2020.104288

Babatunde EO, Saka HB, Olutoye MA, Akpan UG, Auta M (2020b) Synthesis of fatty acid methyl ester from used vegetable oil using activated anthill as catalyst. Niger J Tech 39(1):140147. http://dx.doi.org/10.4314/njt.v39i1.15

Birla A, Singh B, Upadhyay SN, Sharma YC (2012) Kinetics studies of synthesis of biodiesel from waste frying oil using a heterogeneous catalyst derived from snail shell. Biores Tech 106:95-100. https://doi.org/10.1016/j.biortech.2011.11.065

Changmai B, Vanlalveni C, Ingle AP, Bhagat R, Rokhum L (2020) Widely used catalysts in biodiesel production: A review. RSC Adv 10:41625-41679. https://doi.org/10.1039/D0RA07931F

Chhetri AB, Watts KC, Islam MR (2008) Waste cooking oil as an alternate feedstock for biodiesel production. Energies, 1(1):3-18. https://doi.org/10.3390/en1010003

Chinyere BE, Callistus NU, Okechuckwu DO (2017) Optimization of the methanolysis of lard oil in the production of biodiesel with response surface methodology Egypt J Pet 26(4):10011011. https://doi.org/10.1016/j.ejpe.2016.12.004 
430 Ciriminna R, Fidalgo A, Pandarus V, Beland F, IIharco LM, Pagliaro M (2013) The sol-gel route 431 to advance silica-based materials and recent applications. Chem Rev 113(8):6592-6620. 432 https://doi.org/10.1021/cr300399c

433 Dawodu FA, Ayodele O, Xin J, Zhang S, Yan D (2014) Effective conversion of non-edible oil 434 with high free fatty acid into biodiesel by sulphonated carbon catalyst. Appl. Energy 114:819435 826. http://dx.doi.org/10.1016/j.apenergy.2013.10.004

436 Deshmane VG, Adewuyi YG (2013) Synthesis and kinetics of biodiesel formation via calcium 437 methoxide base catalyzed transesterification reaction in the absence and presence of ultrasound. 438 Fuel 107:474-482. http://dx.doi.org/10.1016/j.fuel.2012.12.080

439 Dhawane SH, Karmakar B, Ghosh S, Halder G (2018) Parametric optimization of biodiesel 440 synthesis from waste cooking oil via Taguchi approach. J Env Chem Eng 6:3971-3980. 441 https://doi.org/10.1016/j.jece.2018.05.053

442 Enagbonma BJ, Babalola OO (2019) Environmental sustainability: A review of termite mound 443 soil material and its bacteria. Sustainability 11(14):38-47. https://doi.org/10.3390/su11143847

444 Endalew AK, Kiros Y, Zanzi R (2011) Inorganic heterogeneous catalysts for biodiesel 445 production from vegetable oils. Biomass Bioener 35:3787-3809.

446 Fadhila BB, Emaad TBA, Albadreeb MA (2017) Biodiesel production from mixed non-edible 447 oils, castor seed oil and waste fish oil. Fuel 210:721-728. $448 \quad$ https://doi.org/10.1016/j.fuel.2017.09.009

449 Farook A, Balakrishnan S, Wong P (2006) Rice husk ash silica as a support material for 450 ruthenium based heterogeneous catalyst. J Phys Sci 17(2):1-13.

451 Farooq M, Ramli A, Naeem A (2015) Biodiesel production from low FFA waste cooking oil 452 using heterogeneous catalyst derived from chicken bones. Renew Energy, 76:362-368. 453 https://doi.org/10.1016/i.renene.2014.11.042

454 Feyzi M, Shahbazi Z (2017) Preparation, kinetic and thermodynamic studies of Al-Sr 455 nanocatalysts for biodiesel production. J Taiwan Inst Chem Eng 71:145-155. 456 https://doi.org/10.1016/j.jtice.2016.11.023 
457 Figueiredo M, Fernando A, Martins G, Freitas J (2010) Effect of the calcination temperature on 458 the composition and microstructure of hydroxyapatite derived from human and animal bone. 459 Ceram Int 36(8):2383-2393. https://doi:10.1016/j.ceramint.2010.07.016

460 Ganguli AK, Kumar S, Baruah A, Vaidya S (2013) Nanocrystalline silica from termite mounds. 461 Curr Sci 106(1):83-88.

462 Hossain MN, Siddik Bhuyan MSU, Md Ashraful Alam AH, Seo YC (2019) Optimization of 463 biodiesel production from waste cooking oil using $\mathrm{S}-\mathrm{TiO}_{2} / \mathrm{SBA}-15$ heterogeneous acid catalyst. 464 Catalysts 9(1):67. https://doi.org/10.3390/catal9010067

465

466

467 468

469

470

471

472

473

474

475

476

477

478

479

480

481

482

483

484

Jain S, Sharma MP, Rajvanshi S (2011) Acid base catalyzed transesterification kinetics of waste cooking oil. Fuel Proc Tech 92(1):32-38. https://doi.org/10.1016/j.fuproc.2010.08.017

Jung J, Ohb J, Baekc K, Leed J, Kwona EE (2018) Biodiesel production from waste cooking oil using biochar derived from chicken manure as a porous media and catalyst. Energy Conv Manage, 165:628-633. https://doi.org/10.1016/j.enconman.2018.03.096

Karmakar B, Dhawane SH, Halder G (2018) Optimization of biodiesel production from castor oil by Taguchi design. J Env Chem Eng 6:2684-2695. https://doi.org/10.1016/j.jece.2018.04.019

Karmakar B, Ghosh B, Samanta S, Halder G (2020a) Sulfonated catalytic esterification of Madhuca indica oil using waste Delonix regia: L16 Taguchi optimization and kinetics. Sust Energy Tech Assess 37:100568. https://doi.org/10.1016/j.seta.2019.100568

Karmakar B, Ghosh B, Halder G (2020b) Sulfonated Mesua ferrea linn seed shell catalyzed biodiesel synthesis from castor oil - Response surface optimization. Front Energy Res 8:576792. https://doi.org/10.3389/fenrg.2020.576792

Karmakar B and Halder G (2019) Progress and future of biodiesel synthesis: Advancements in oil extraction and conversion technologies. Energy Conv Manage 182:307-339. https://doi.org/10.1016/j.enconman.2018.12.066

Karmakar B, Hossain A, Jha B, Sagar R, Halder G. (2021) Factorial optimization of biodiesel synthesis from castor-karanja oil blend with methanol-isopropanol mixture through acid/base doped Delonix regia heterogeneous catalysis. Fuel 285:119197. https://doi.org/10.1016/j.fuel.2020.119197 
Karmakar B, Samanta S, Halder G (2020c) Delonix regia heterogeneous catalyzed two-step biodiesel production from Pongamia pinnata oil using methanol and 2-propanol. J Clean Prod 255:120313. https://doi.org/10.1016/j.jclepro.2020.120313

Krishnamurthy KN, Sridhara SN, Ananda K (2020) Optimization and kinetic study of biodiesel production from Hydnocarpus wightiana oil and diary waste scum $\mathrm{CaO}$ nano catalyst. Renew Energy 146:280-296. https://doi.org/10.1016/j.renene.2019.06.161

Kumar M and Sharma MP (2015) Assessment of potential of oils for biodiesel production. Renew Sust Energy Rev 44:814-823. https://doi.org/10.1016/j.rser.2015.01.013

Kusuma M and Chandrappa GT (2019) Effect of calcination temperature on characteristic properties of CaMoO4 nanoparticles. J Sci Adv Mater Dev 4(1):150-157. https://doi.org/10.1016/j.jsamd.2019.02.003

Laskar IB, Rajkumari K, Gupta R, Chatterjee S, Paul B, Rokhum, L (2018) Waste snail shell derived heterogeneous catalyst for biodiesel production for thee transesterification of soybean oil. RSC Adv, 8:20131-20142. https://doi.org/10.1039/c8ra02397b

Lesbani A, Tamba P, Mohadi R, Fahmariyanti (2013) Preparation of calcium oxide from Achatina fulica as catalyst for production of biodiesel from waste cooking oil. Indones J Chem 13(2):176-180.

Ma Y, Wang Q, Sun X, Wu C, Gao Z (2017) Kinetic studies of biodiesel production from waste cooking oil using $\mathrm{FeCl}_{3}$-modified resin as heterogeneous catalyst. Renew Energy 107:522-530. https://doi.org/10.1016/j.renene.2017.02.007

Minh ACL, Quitainb AT, Lama MK, Yusupa S, Sasakid M, Kidab T (2019) Development of high microwave-absorptive bifunctional graphene oxide based catalyst for biodiesel production. Energy Conv Manage 180:1013-1025. https://doi.org/10.1016/j.enconman.2018.11.043

Mitaphonna R, Ramli M, Maulana I, Novita D, Zahara I, Wardani R (2019) Preparation of heterogenous catalyst of aceh cow bone material and its catalytic performance for biodiesel synthesis. Int Proc Asia Youth Conf 2599-2643. https://doi:10.5281/zenodo.2549060

Moradi GR, Mohadesi M, Ghanbari M, Moradi MJ, Hosseini SH, Davoodbeygi Y (2015) Kinetic comparison of two basic heterogeneous catalysts obtained from sustainable resources for transesterification of waste cooking oil. Biofuel Res J 6:236-241. 
514 Nisar J, Razaq R, Farooq M, Iqbal M, Khan RA, Sayed M, Rahman I (2017) Enhanced biodiesel 515 production from Jatropha oil using calcined waste animal bones as catalyst. Renew Energy 101:111-119. https://doi.org/10.1016/j.renene.2016.08.048

517 Olutoye MA and Hammed BH (2013) A highly active clay-based catalyst for the Synthesis of 518 fatty acid methyl ester from waste cooking palm oil. Appl Cat A 450:57-62. https://doi.org/10.1016/j.apcata.2012.09.049

520 Owolabi RU, Osiyemi NA, Amosa MK, Ojewumi ME (2011) Biodiesel from 521 household/restaurant waste cooking oil (WCO). J Chem Eng Proc Tech 2(4):1-4 522 https://doi.org/10.4172/2157-7048.1000112

523 Paulino I and Schuchardt U (2002) Studies of MCM-41 obtained from different sources of silica. 524 Stud Surf Sci Catal 141:93-100. https://doi.org/10.1016/S0167-2991(02)80529-8

525 Polshettiwar V, Len C, Fihri A (2009) Silica-supported palladium: Sustainable catalysts for cross 526 coupling reactions. Coord

Chem Rev 253(21-22):2599-2626

$527 \quad$ https://doi.org/10.1016/j.ccr.2009.06.001

528 Putra DM, Irawan P, Ristianingsih Y, Nata IF (2018) A cleaner process of biodiesel production 529 from waste cooking oil using materials as a heterogeneous catalyst and its kinetic study. J Clean 530 Prod 195:1249-1258. https://doi.org/10.1016/j.jclepro.2018.06.010

531 Rachael W and Denise B (2012) An investigation of restaurant waste oil characteristics for 532 biodiesel production in Trinidad and Tobago. Energy Sustain Dev 16(4):515-519. 533 https://doi.10.1016/j.esd.2012.05.005

534 Samart C, Chaiya C, Reubroycharoen P (2010) Biodiesel production by methanolysis of 535 soyabean oil using calcium supported on mesosilica catalyst. Energy Conv Manag 51(7):1428536 1431. https://doi.org/10.1016/j.enconman.2010.01.017

537 Shaikh, AA, Joshi PN, Jacob NE, Shiralkar VP (1993) Direct hydrothermal crystallization of 538 high- silica large-port mordenite. Zeolites 13(2):511-517. https://doi.org/10.1016/0144$539 \underline{2449(93) 90227-T}$

540 Tangboriboon N, Kunanuruksapong A, Sirivat A (2012) Preparation and properties of calcium 541 oxide from eggshells via calcination. Mater Science Poland 30(4):313-322. 542 https://doi:10.2478/s13536-012-0055-7 
543 Tan KT, Gui MM, Lee KT, Mohamed AR (2010) An optimization study of methanol and ethanol

544 in supercritical alcohol technology for biodiesel production. J Supercrit Fluids 53(1-3):82-87.

545 https://doi:10.1016/j.supflu.2009.12.017

546 Varadwaj GBB, Rana S, Parida KM (2013) Amine functionalized K10 montmorillonite: a solid

547 acid base catalyst for the knoevenagel condensation reaction. Dalton Trans 42(14):5122-5129.

548 https://doi.org/10.1039/C3DT32495H

549 Xiang-nan Z, Xian-jun L, Qiang W, Jun Q, Sha-sha W, Xin-yu L, Lin L (2019) Clean utilization

550 of waste oil: Soap collectors prepared by alkaline hydrolysis for fluorite flotation. J Clean Prod 551 240:118179. https://doi.org/10.1016/j.jclepro.2019.118179

552 Yusuff AS, Adeniyi OD, Azeez SO, Olutoye MA, Akpan UG (2018) Synthesis and 553 characterization of anthill-eggshell-Ni-Co mixed oxides composite catalyst for biodiesel 554 production from waste frying oil. Biofuel Bioprod Bioref 13(1):37-47. 555 https://doi.org/10.1002/bbb.1914

556 Yusuff AS, Adeniyi OD, Olutoye MA, Akpan UG (2017) Kinetic study of transesterification of 557 waste frying oil to biodiesel using anthill-eggshell-Ni-Co mixed oxide composite catalyst. Pet 558 Coal 60(1):157-167. Available at: https://www.researchgate.net/publication/324834185

559 Zabeti M, Daud WMAW, Mohamed KA (2009) Activity of solid catalysts for biodiesel 560 production: A review. Fuel Proc Tech 90(6):770-777.

561 https://doi.org/10.1016/j.fuproc.2009.03.010

562 Zhang J, Chen S, Yang R, Yan J (2010) Biodiesel production from vegetable oil using 563 heterogeneous acid alkali catalyst. Fuel 89(10):2939-2944.

564 https://doi.org/10.1016/j.fuel.2010.05.009 
Figures

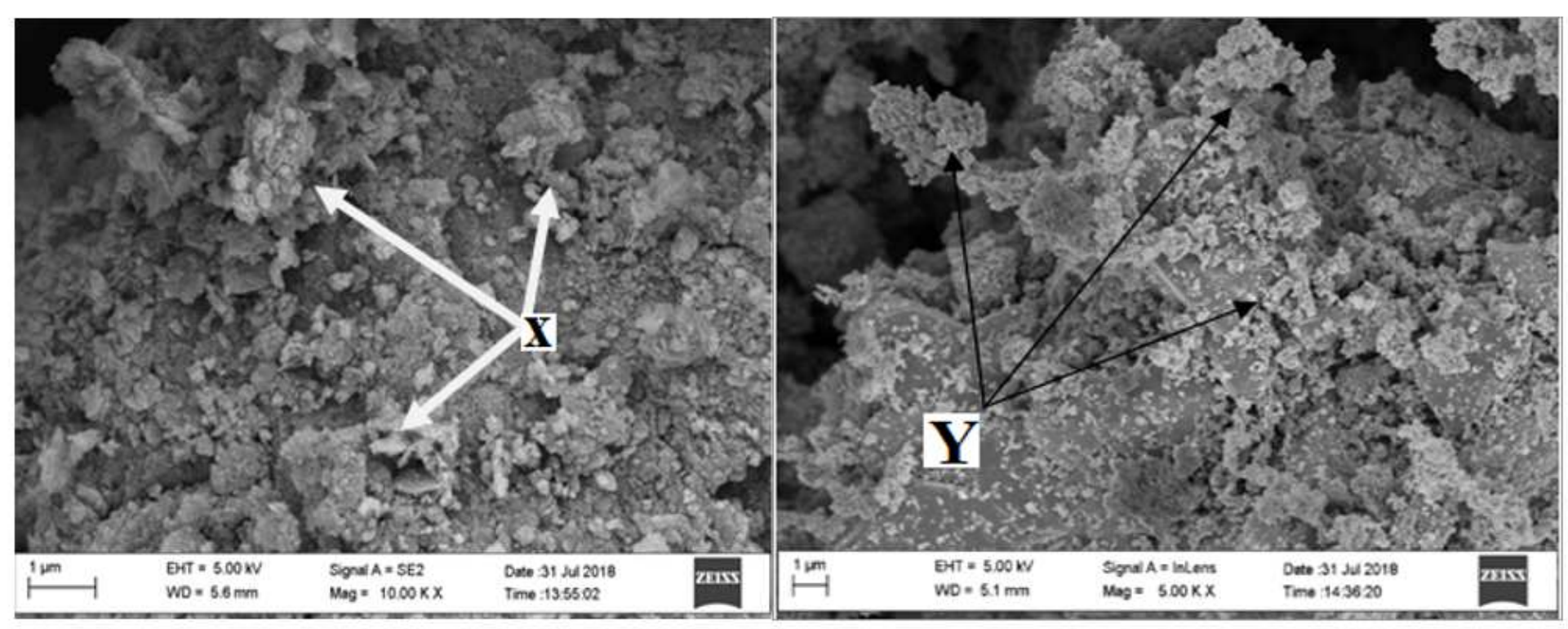

Figure 1

SEM Image of (a) R - SC1.5 and (b) K $\neg$ - SC1.5

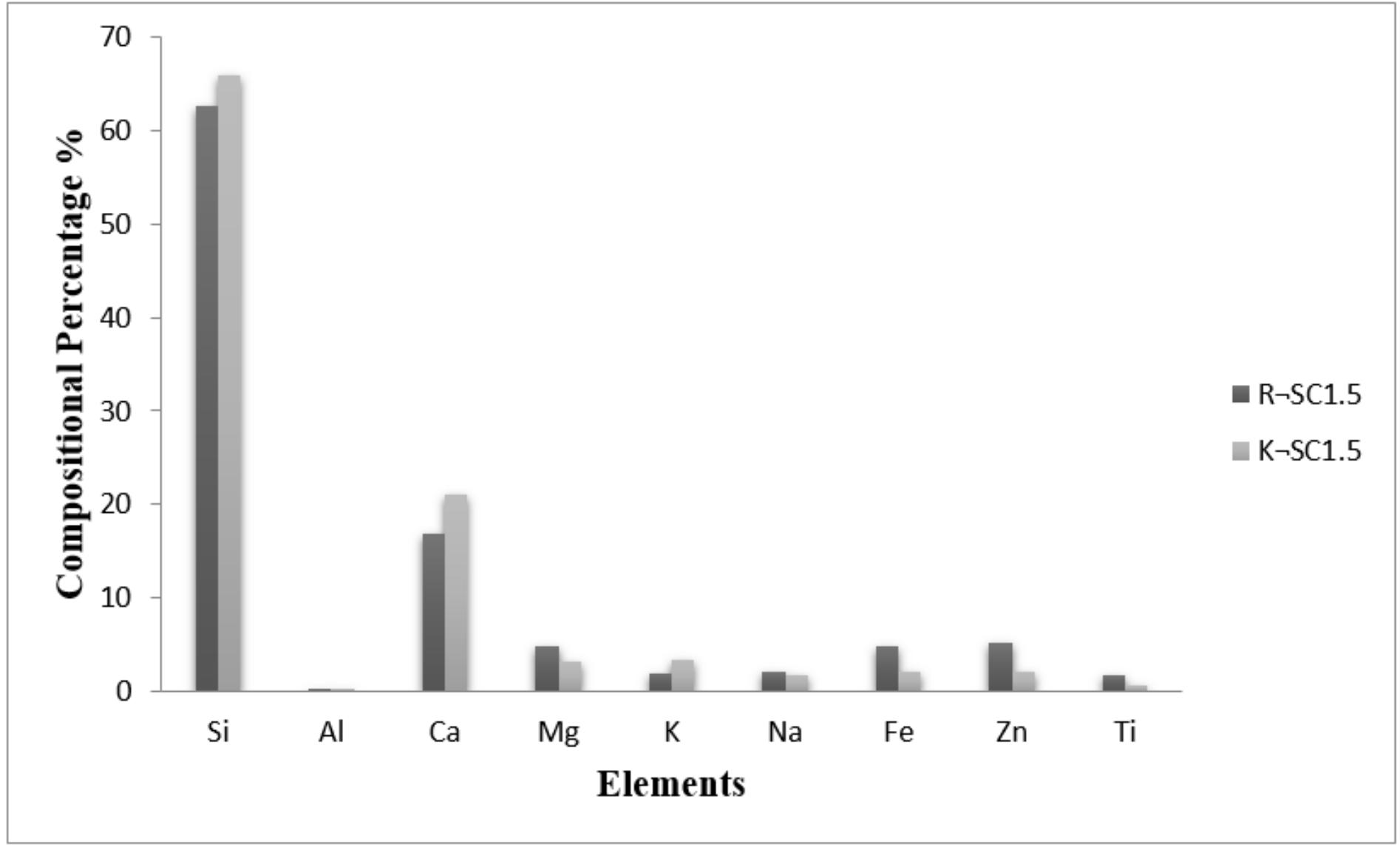

Figure 2 
EDX analysis of the R - SC1.5 and $\mathrm{K}\urcorner-\mathrm{SC} 1.5$

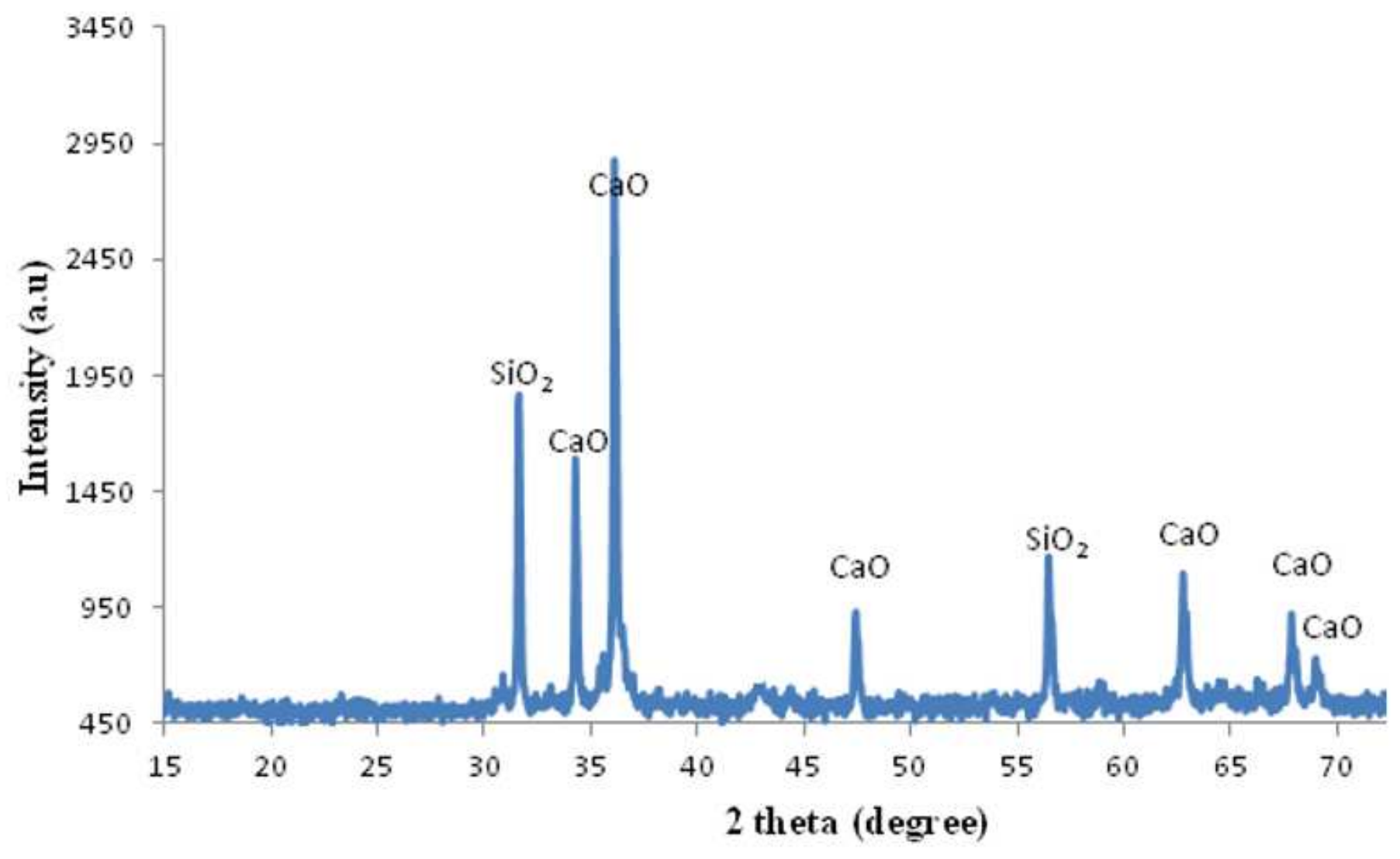

Figure 3

XRD Spectrum of $\mathrm{K}\urcorner-\mathrm{SC} 1.5$ 


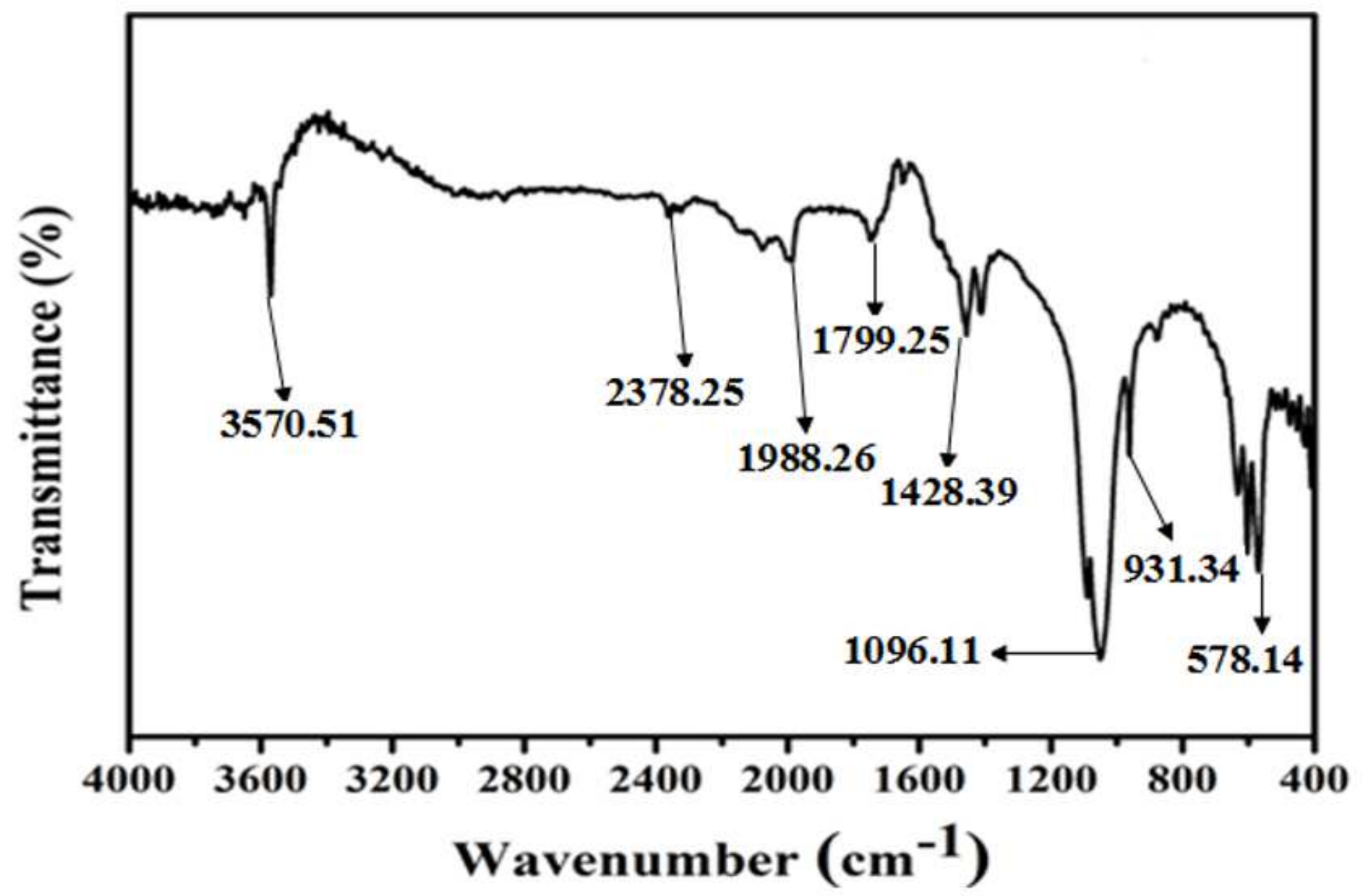

Figure 4

FTIR Spectrum of $\mathrm{K}\urcorner-\mathrm{SC} 1.5$ 


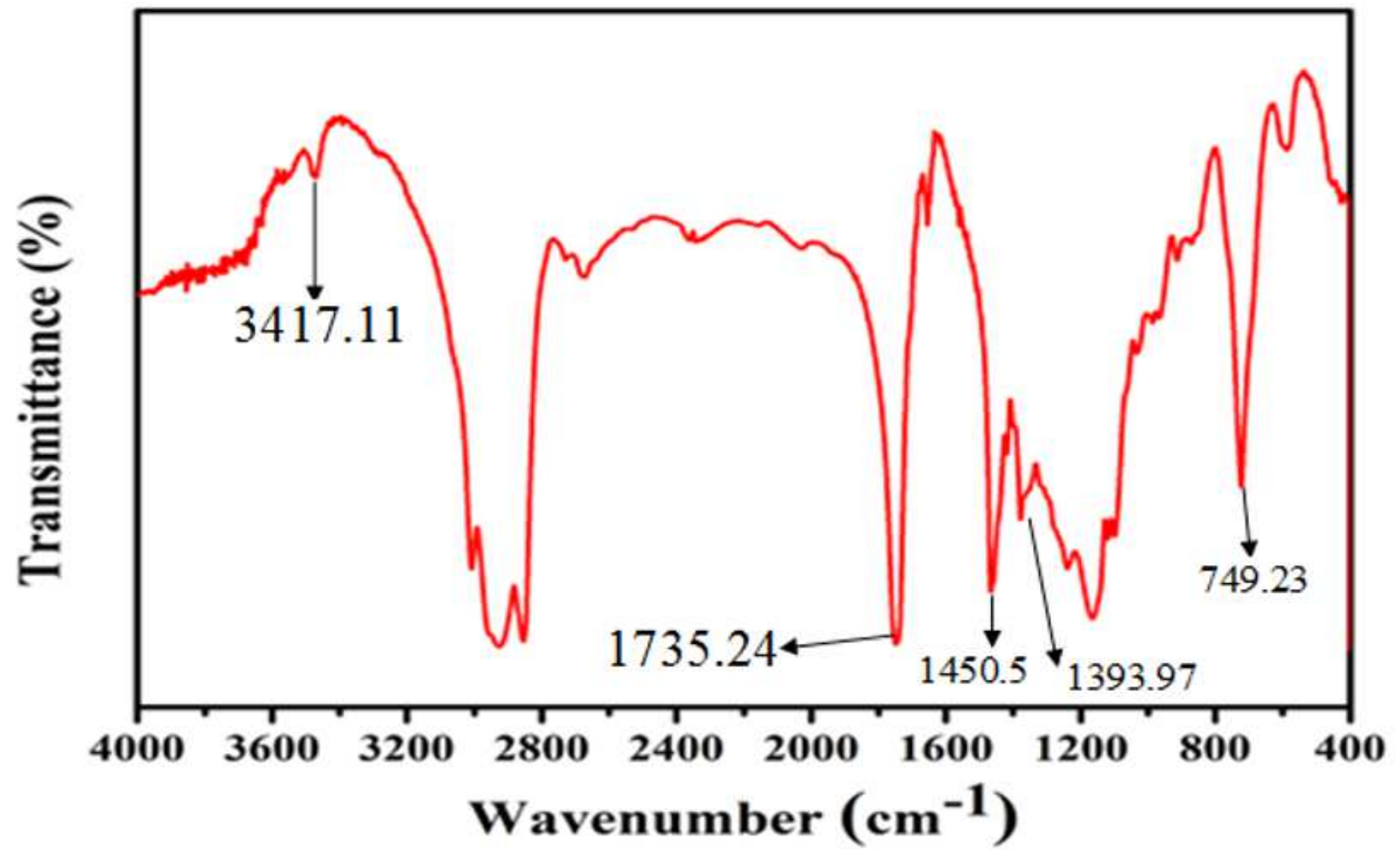

Figure 5

FTIR spectrum for biodiesel produced form $\mathrm{K}\urcorner-\mathrm{SC} 1.5$ at $65^{\circ} \mathrm{C}$ after $2.5 \mathrm{~h}$ 


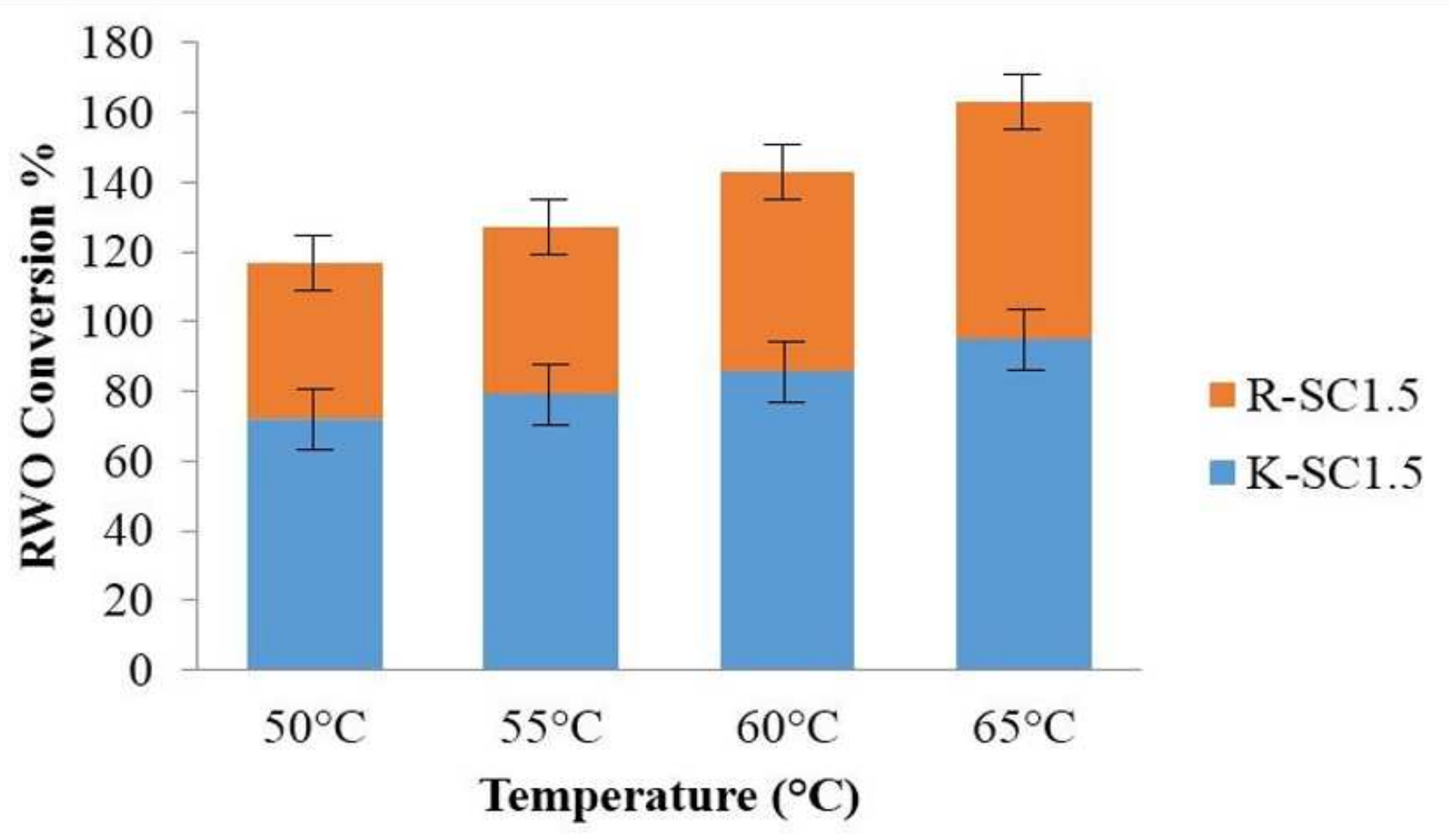

Figure 6

Maximum biodiesel conversion for R - SC1.5 and $\mathrm{K} \neg-\mathrm{SC} 1.5$ after $2.5 \mathrm{~h}$
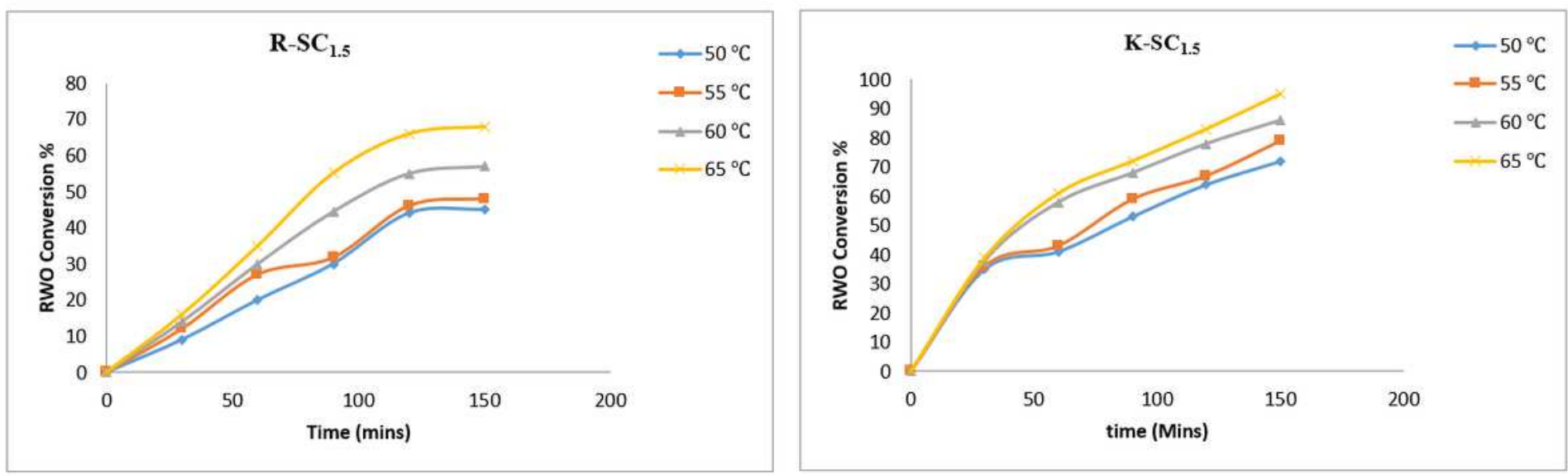

Figure 7

a Effect of temperature and time of RWO conversion (R-SC1.5) b Effect of temperature and time of RWO conversion (K-SC1.5) 

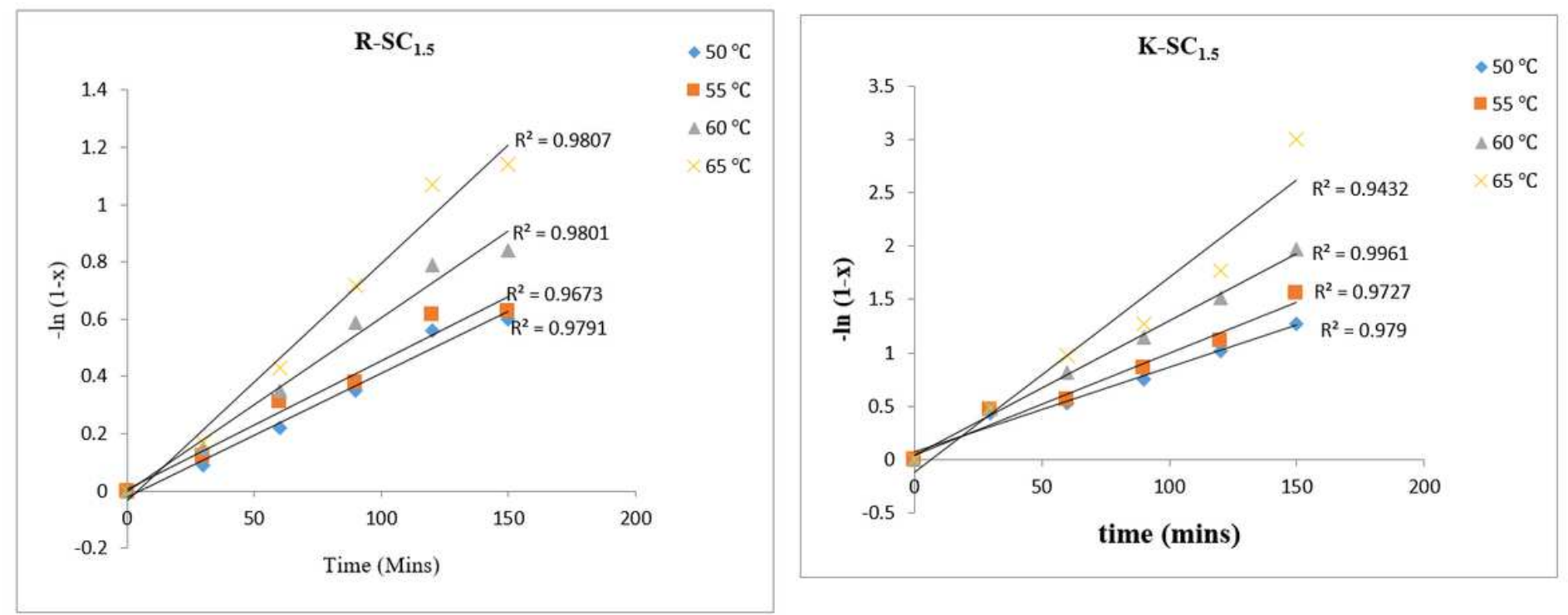

Figure 8

plot of $-\ln (1-X)$ against $t$

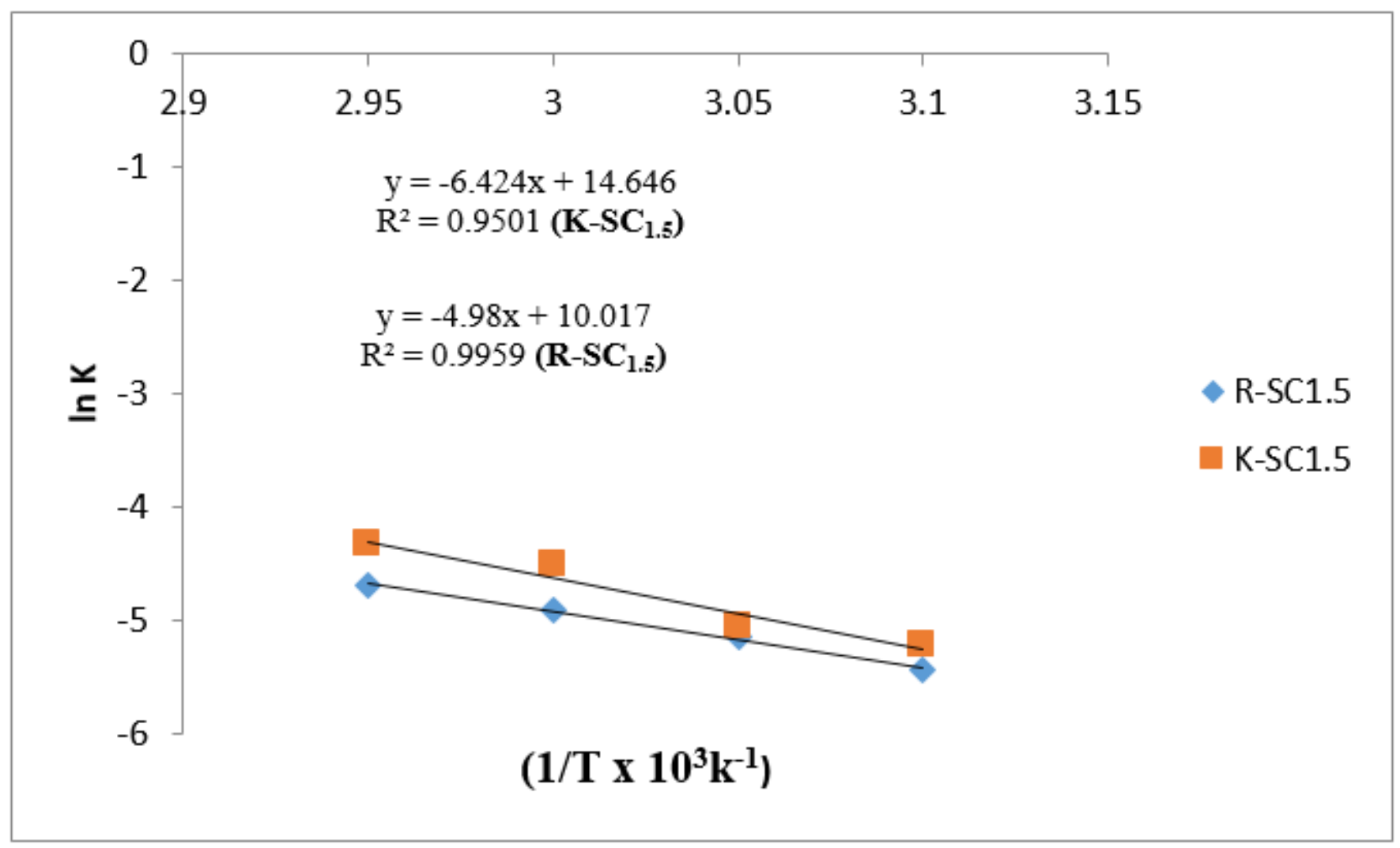

Figure 9

Plot of In K against 1/T x 10-3 (R-SC1.5 and K-SC1.5) 


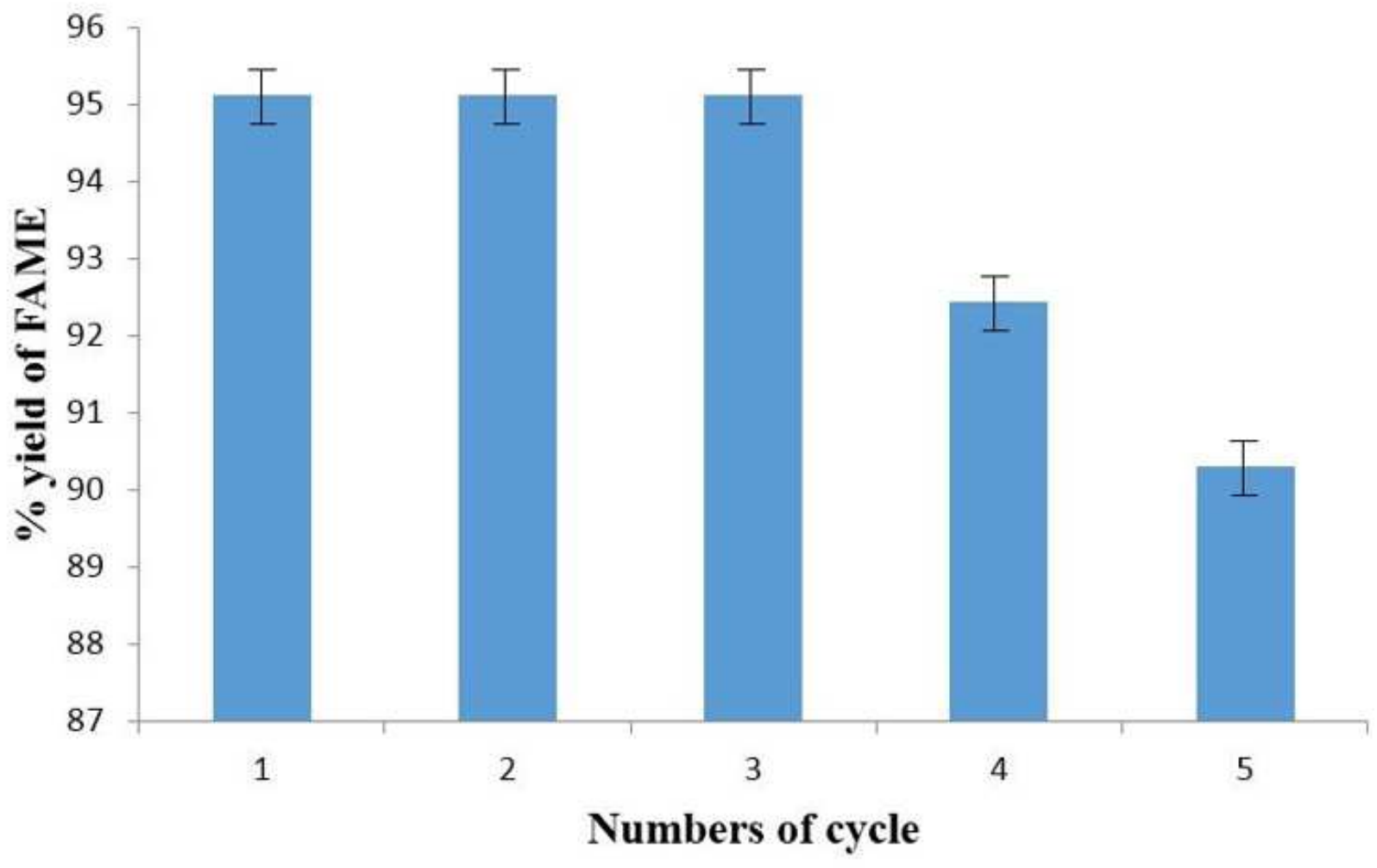

Figure 10

Reusability study of K-SC1.5 catalyst 